produce surpluses of food throughout the European Community could be used instead to improve the quality of accommodation available to homeless and badly housed people.

I hope my examples will make it clear that I do not think that Professor Lilford should wait for elections before acting to promote the interests of poor people. Clearly he cannot expect to achieve such changes without sometimes working with others who share the implied objectives. On the other hand, he has special opportunities. On the day he took up his chair in Leeds, for example, he was interviewed by Yorkshire Television. As a relatively influential member of society, he will no doubt be presented with many similar opportunities to promote the interests of disadvantaged people. I shall be watching future developments in social class differences in fetal and neonatal mortality rates in Leeds with special interest.

National Perinatal Epidemiology Unit,

IAIN Chalmers Radcliffe Infirmary,

Oxford $\mathrm{OX} 26 \mathrm{HE}$

\section{Emergencies at sea}

SIR,-I have read with interest the correspondence generated by your article "Doctors at Sea" (13 July, p 156; 3 August, p 344; 24 August, p 545). Twice during the past five years, while travelling as a ship's passenger, I have been confronted with a potentially life threatening emergency. The first occurred at the midpoint of an 18 hour crossing and concerned a young married woman who had developed abdominal pain and fresh vaginal bleeding after six weeks' amenorrhoea. The second occurred at the midpoint of a 12 hour crossing and concerned a young asthmatic boy who had become increasingly wheezy; his inhaler had run out 24 hours previously. Fortunately, both patients remained stable, were met at their destination by an emergency ambulance, and, to my knowledge, made a full recovery. Like the previous correspondents, I was dismayed at the lack of relevant medical equipment on board ship.

Legislation regarding medical supplies on board ship is stipulated in statutory instruments; the current regulations for medical supplies on board passenger ferries were laid down in $1974,{ }^{1}$ with minor amendments in $1975^{2}$ and 1980. "Passenger ships" (those carrying more than 12 passengers) that operate in the Irish Sea, the English Channel, and the North Sea, including those reaching as far afield as Narvik in Norway and Corunna in northern Spain, are not obliged to carry a doctor (or nurse) on any voyage; they fall within scale III in the schedule relating to

TABLE I-Present regulation items for medical supplies kit on board passenger ferries, according to current legislation

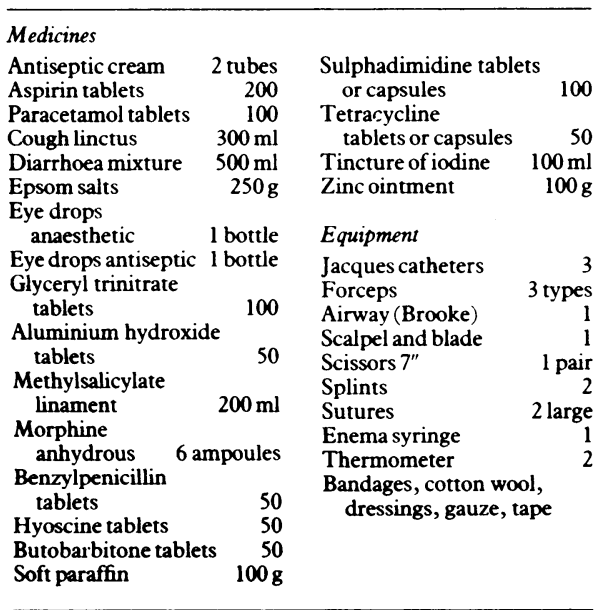

TABLE II-Additional items of medical equipment recommended for passenger ferries

\begin{tabular}{lccc}
\hline & $\begin{array}{c}\text { Unit } \\
\text { cost }(\mathfrak{E})\end{array}$ & Quantity & $\begin{array}{c}\text { Total } \\
\text { cost }(\mathfrak{E})\end{array}$ \\
\hline $\begin{array}{l}\text { Capital items } \\
\text { Stethoscope }\end{array}$ & $\begin{array}{c}c 50 \\
\text { Sphygmomanometer }\end{array}$ & & \\
\hline \multicolumn{1}{c}{ Total } & & \\
\hline Disposable equipment & & & 100 \\
IV Cannulas & 1.50 & 4 & 6 \\
Giving set & 3 & 2 & 6 \\
10 ml syringe & 0.15 & 10 & 1.50 \\
5 ml syringe & 0.15 & 10 & 1.50 \\
21 g needle & 0.05 & 10 & 0.50 \\
27 g needle & 0.05 & 10 & 0.50 \\
Oxygen cylinder & 30 year & 1 & 30 \\
Oxygen 740 1 & 8 & 1 & 8 \\
Face mask and tubing & 5 & 4 & 20 \\
\hline \multicolumn{1}{c}{ Total } & & & 74.00 \\
\hline
\end{tabular}

\begin{tabular}{|c|c|c|c|}
\hline \multicolumn{4}{|l|}{$\begin{array}{l}\text { Drugs and fluids } \\
\text { Physiological saline }\end{array}$} \\
\hline & 1.50 & 4 & 6 \\
\hline $\begin{array}{l}\text { Haemaccel } 500 \mathrm{ml} \\
50 \% \text { Dextrose }\end{array}$ & $4 \cdot 25$ & 4 & 17 \\
\hline $\begin{array}{l}20 \mathrm{ml} \text { injection } \\
\text { Pethidine }\end{array}$ & $1 \cdot 25$ & 4 & 5 \\
\hline $\begin{array}{l}\text { injection } 50 \mathrm{mg} \\
\text { Prochlorperazine }\end{array}$ & $0 \cdot 12$ & 4 & 0.50 \\
\hline $\begin{array}{l}\text { injection } 12.5 \mathrm{mg} \\
\text { Frusemide injection }\end{array}$ & 0.30 & 3 & 1 \\
\hline $\begin{array}{l}20 \mathrm{mg} \\
50 \mathrm{mg}\end{array}$ & $\begin{array}{l}0.30 \\
0.50\end{array}$ & 6 & $\begin{array}{l}2 \\
0.50\end{array}$ \\
\hline $\begin{array}{l}\text { Aminophylline } \\
\text { injection } 250 \mathrm{mg}\end{array}$ & 0.50 & 2 & 1 \\
\hline $\begin{array}{l}\text { Diazepam } \\
\text { injection } 10 \mathrm{mg} \\
2 \% \text { Lignocaine } 5 \mathrm{ml}\end{array}$ & $\begin{array}{l}0.30 \\
0.15\end{array}$ & $\begin{array}{l}6 \\
6\end{array}$ & $\begin{array}{l}2 \\
1\end{array}$ \\
\hline & & & $6 \cdot 0$ \\
\hline
\end{tabular}

mandatory medical supplies. The regulation supply for this scale (table I) includes a range of first aid equipment, dressings, and drugs, some of which are general purpose and some specific to the needs of sea travel. There are a few puzzling inclusions-for example, five litres of liquid insecticide. Only one parenteral agent is included-namely, morphine. 100 tablets of glyceryl trinitrate are listed, but there is no other agent apposite to the needs of a range of treatable medical emergencies-for example, acute heart failure, acute asthma, and hypoglycaemic or epileptic events. The list does not include a stethoscope, sphygmomanometer, or equipment for establishing an intravenous infusion, and none of these were available during the crossings on which I met my emergencies

Table II lists additional equipment and drugs that might help a doctor faced with an emergency on a passenger ferry that does not carry full time medical staff. These additional facilities would cover most medical emergencies, possibly providing life saving support until further help became available. (I have reservations whether the equipment for advanced airway management suggested by Drs J P H Fee and J Moore would be of use to most medical practitioners, most of whom do not regularly practise resuscitation and airway management (Ambu bag and endotracheal equipment) in their professional lives. Furthermore, the poor prognosis for collapsed patients requiring emergency endotracheal intubation even in hospital would make it difficult to justify including this equipment, which at about $£ 300$ is relatively expenequipme
sive.)

The costs of the items in table II were obtained independently in two NHS hospitals, are non-contract

non-hospital prices, and include value added tax at $15 \%$. The shortest shelf life of the drugs and fluids selected is two years, and some survive much longer (pethidine 5 years and Haemaccel 8 years). None the less, it is safest and probably logistically simplest to replace completely all disposable equipment, drugs, and fluid once a year.

These recommendations would result in additional capital expenditure of $£ 100$ and additional annual expenditure on disposable items of $£ 110$. Even with administrative costs the overall additional expense per ship each year would be about
$£ 200$ the equivalent of two return trips for a small car. It must compare very favourably with the cost of an air-sea rescue and very favourably with the price of human life. The medical profession surely has a duty to voice its concern before one of its members is involved in such a tragedy while standing by, willing but helpless. To a shipping company, the sums needed to equip a ferry more adequately can be but a drop in the ocean. "A drop in the ocean" from a Wessex rescue helicopter costs on average $£ 4500$ an hour.

D N S GLEADHILL

Accident and Emergency Department,

Walton Hospital,

Liverpool L9 1AE

The merchant shipping (medical scales) regulations 1974. London: HMSO, 1974 (SI 1193).

2 The merchant shipping (medical scales) (amendment) regulations 1975. London: HMSO, 1975 (SI 1581). 3 The merchant shipping (medical scales) (amendment) regulations
1980. London: HMSO, 1980 (SI 407).

Neonatal hypoglycaemia: an important early sign of endocrine disorders

SIR,-The timely review by Dr R Stanhope and Dr C G D Brook emphasises the importance of endrocrine disorders as a cause of neonatal hypoglycaemia (14 September, p 728). We have recently reviewed all cases of hypoglycaemia which presented to our neonatal unit over a two year period ending in December 1984 and would like to draw attention to some practical points highlighted by our study.

During this period there were 6665 deliveries ( 6627 liveborn); 43 infants ( 19 girls and 24 boys) with a blood glucose concentration less than $1 \mathrm{mmol} / 1(18 \mathrm{mg} / 100 \mathrm{ml})$ required treatment. Sixteen were preterm and eight post-term and in 17 the birth weight was less than the 10 th centile for gestational age. Other contributory factors identified were: hypothermia in 20 , fetal distress in 11 , maternal beta blocker treatment in 5, maternal diabetes in 1, paternal diabetes in 1 , and endocrinopathy in 6.

Hypothermia (rectal temparature less than $36^{\circ} \mathrm{C}$ ) was by far the most common contributing factor. It occurred alone in five cases. In the endocrine group one infant had hypopituitarism, one septo-optic dysplasia, and four transient hyperinsulinism. In the infant with hypopituitarism a very low maternal urinary oestriol excretion was attributed to placental steroid sulphatase deficiency. A considerable reduction in maternal urinary oestriol excretion is found in both conditions, but they can be differentiated antenatally. ${ }^{12}$ This knowledge would alert the paediatrician to expect problems with glucose homoeostasis in the infant with hypopituitarism. One male term infant, large for dates, who was hypoglycaemic at 4 hours of age, had no obvious contributory factors, although his father was an insulin dependant diabetic. We are aware of the suggestion that diabetes may be more common in the offspring of diabetic fathers than in those of diabetic mothers, ${ }^{3}$ but have not heard of an association with neonatal hypoglycaemia. We would be interested to hear of any previous experience.

Twenty nine out of 43 infants were asymptomatic at the time of diagnosis, emphasising the importance of screening infants at risk. Clearly simple attention to thermal stability and early calorie intake are still the most important factors in preventing hypoglycaemia in most cases.

ANN M SUTtON

Royal Hospital for Sick Children, JOHN C P KINGDOM

Glasgow G3 8S 
1 Harkness RA, Taylor NF, Crawfurd MA, Rose FA. Recognising placental steroid sulphatase deficiency. $\mathrm{Br}$ Med $\mathcal{f}$ 1983;287: 2-3.

2 Oakley R E. Antenatal detection of placental steroid sulphatase deficiency: use of a dehydroepiandrosterone sulphate loading test. Brf Obstet Gynaecol 1984;91:337-41.

3 Warram JH, Krolewski AS, Gottlieb MS, Kahn CR. Differences in risk of insulin-dependent diabetes in offspring of diabetic mothers and diabetic fathers. $N$ Engl $\mathcal{F}$ Med 1984;311:149-52.

\section{Nocturnal hypoglycaemia in patients} receiving conventional treatment with insulin

SIR,-The study by Dr S Pramming and colleagues (10 Aug, p 376) raises the important point of what one means by nocturnal hypoglycaemia The authors took this to be a blood glucose concentration of below $3 \mathrm{mmol} / \mathrm{l}(55 \mathrm{mg} / 100 \mathrm{ml})$, although this widely accepted lower limit of blood glucose concentration has been derived from daytime studies on normal subjects. The fact is that we do not know what constitutes an abnormally low blood glucose value during sleep. Consequently to label their patients as having "nocturnal biochemical hypoglycaemia" may be misleading. It is perhaps no surprise that none of the affected 47 patients woke up or developed any nocturnal symptoms during their period of so called nocturnal hypoglycaemia.

Studies on nocturnal variation of blood glucose concentrations in non-diabetic and diabetic individuals have shown that low glucose concentrations may be obtained during sleep with no nocturnal symptoms or subsequent sequelae. ${ }^{1}$ In both insulin and non-insulin dependent diabetics receiving treatment the blood glucose concentration declines during sleep and drops to its lowes level between 0200 and $0400^{2}$; thereafter there is rise known as the dawn phenomenon. ${ }^{34}$ The low glucose values that Dr Pramming and others have detected in their diabetic patients may therefore be no more than an accentuation of the physiological norm.

Furthermore, the absence of the Somogyi effect in their patients lends support to the possibility that significant nocturnal hypoglycaemia did not occur and consequently there was no rebound hypoglycaemic effect. The presence of a Somogyi effect after hypoglycaemia induced by insulin has been well documented in diabetics at least during the day. ${ }^{5}$

The question of nocturnal hypoglycaemia in patients on conventional insulin treatment is obviously one of great therapeutic importance. Physicians assess control in their diabetic patients by measuring blood glucose concentrations during waking hours. Perhaps we also now need to ask whether we are achieving good nocturnal control or whether in some cases we are even "overcontrolling" at night. Satisfactory answers to these questions cannot be obtained unless the physiological norms of nocturnal blood glucose are known.

A final point of interest. Could Dr Pramming and his colleagues tell us what the lowest recorded nocturnal glucose value was for their interesting patient who developed a hemiparesis the nex morning? He might perhaps have been the only one with significant nocturnal hypoglycaemia.

Department of Medicine,

PHILIP C W LYN

Duchess of Kent Hospital

Sandakan, Sabah, Malaysia

1 Falman C, Moorhouse JA. Diurnal variation in the levels of glucose and related substances in healthy and diabetic subjects during starvation. Clin Sci 1967;32:111-26,

2 Riddle MC. New tactics for type 2 diabetics: regimens based on intermediate acting insulins taken at bedtime. Lancet 1985;i:192-4.

3 Bolli GB, Gerrich JE. The dawn phenomenon-a common occurrence in both non-insulin and insulin dependent diabetes mellitus. N Engl f Med 1984;310:746-50.
4 Schmidt MI, Lin QX, Gwynne JT, Jacobs S. Fasting early morning rise in peripheral insulin: evidence for the daw morning rise in peripheral insulin: evidence for the

5 Bolli GB, Gottesman IS, Campbell PJ, et al. Glucose counterregulation and waning of insulin in the Somogyi phenomenon NEngl f Med 1984;311:1214-9.

${ }_{*}^{* *}$ The authors reply below.-ED, $B M \mathcal{F}$.

SIR,--Information on nocturnal blood glucose concentrations in non-diabetics has been available for some years. ${ }^{12}$ Overnight blood glucose concentrations in normal subjects are characterised by being remarkably constant, without a trough value between 0200 and 0400 , and seldom below 4 $\mathrm{mmol} / \mathrm{l}(73 \mathrm{mg} / 100 \mathrm{ml})$; in a recent study only two out of 120 overnight measurements were below 4 $\mathrm{mmol} / \mathrm{l}: 3.7$ and $3.8 \mathrm{mmol} / \mathrm{l}(67$ and $69 \mathrm{mg} / 100$ $\mathrm{ml}) .^{3}$

Secondly, what is "significant" hypolycaemia? Dr Lyn seems to use the term synonymously with "symptomatic." We consider a blood glucose leve below $3 \mathrm{mmol} / \mathrm{l}$ to be abnormal. Below this leve cognitive function deteriorates ${ }^{4}$ and hormona counter-regulatory response is triggered. ${ }^{5}$ Furthermore, we found that electroencephalographic changes, indicative of neuronal dysfunction, develop in diabetic patients at a blood glucose leve of around $2 \mathrm{mmol} / 1(36 \mathrm{mg} / 100 \mathrm{ml})^{6}$; the change were similar to those described during hypoxia We therefore find it significant that $29 \%$ of dia betics studied on a random night had blood glucose concentrations below $3 \mathrm{mmol} / 1$ and $9 \%$ below 2 $\mathrm{mmol} / \mathrm{l}$.

Thirdly, the absence of Somogyi effect is not surprising, since studies similar to ours have been unable to substantiate its clinical importance. ${ }^{78}$ In fact the only scientific support for this phenomenon is a recent study in six highly selected diabetics. ${ }^{9}$ Our patient mentioned in Dr Lyn's letter illustrates this well, since he had a mean blood glucose value below $2 \mathrm{mmol} / \mathrm{l}$ overnight and also the lowest fasting blood glucose value in the whole study.

The weak point in insulin therapy is indeed the night time, when most patients and many diabet ologists are asleep. The latter group should no sleep the sleep of the just knowing the prevalence of nocturnal hypoglycaemia in their patients. The only way to establish good overnight glycaemic control may be by means of constant subcutaneous insulin infusion by pump.

Stig Pramming BIRGER THORSTEINSSON CHRISTIAN BINDER

teno Memorial Hospital,

DK-2820 Gentofte, Denmark

1 Johansen K, Hansen AaP. Diurnal serum growth hormone levels in poorly and well controlled juvenile diabetics. Diabetes 1971;20:239-45.

2 Alberti KGMM, Dornhorst A, Rowe AS. Metabolic rhythms in normal and diabetic man. Contemporary topics in the study of diabetes and metabolic endacrinology. New York: AL Press, 1975:45-54

3 Vonesch HJ, Gerold S, Dubach UC, Berger W. Nächtliche Hypoglykämen bei Typ-I-Diabetikern ein unterschätztes Risiko? Schweiz Med Wochenschr 1984;114:1674-8.

4 Theilgaard A, Thorsteinsson B, Pinner EM, et al. Neuropsychological performance of different blood glucose concentrations in type 1 (insulin-dependent) diabetic patients Diabetologia 1984;27:338A

5 Amiel SA, Simonson DC, DeFronzo RA, et al. The rate of glucose fall does not determine the counter regulatory horm response to hypoglycaemia. Diabetologia 1984;27:10A.

6 Pramming S, Thorsteinsson B, Stigsby B, et al. EEG changes during hypoglycaemia in type 1 (insulin dependent) diabetic during hypoglycaemia in type 1 (ins

patients. Diabetologia $1984 ; 27: 321 \mathrm{~A}$.
Gale EAM, Tattersall RB. Unrecognised nocturnal hypoglycaemia in insulin treated diabetics. Lancet 1979; i: 1049-52.

Dornan TL, Peckar CO, Mayon-White V, et al. Unsuspected hypoglycaemia, haemoglobin A and diabetic control. Qf Med 1981;197:31-8.

9 Bolli GB, Gottesman IS, Campbell PJ, et al. Glucose counterregulation and waning of insulin in the Somogyi phenomenon. NEngl F Med 1984;311:1214-9.
Incidence of hyperkalaemia induced by indomethacin

SIR,-We read with interest the report of Dr A Zimran and others on the incidence of hyperkalaemia induced by indomethacin (13 July, p 107). This complication of a non-steroidal anti-inflammatory drug has been attributed to a hyporeninaemic hypoaldosteronism. ${ }^{12}$ We would like to add some data derived from our studies on the influence of indomethacin on renal function and sodium and water homoeostasis in healthy volunteers. ${ }^{3} \mathrm{We}$ showed that indomethacin $75 \mathrm{mg}$ twice a day for four days induced a fall in plasma renin activity and plasma aldosterone concentration in eight healthy human volunteers. ${ }^{3}$ Data on sodium and potassium handling in these subjects are given in the table. Glomerular filtration rate was measured the last day before and the fourth day during indomethacin. The mean of the urinary electrolyte excretions three days before indomethacin was compared with the mean on three days during indomethacin. The Wilcoxon test for paired data was used.

Data on sodium and potassium handling before and during indomethacin treatment. Values are means $(S D)$

\begin{tabular}{|c|c|c|c|}
\hline & Before & During & p Value \\
\hline Inulin clearance $(\mathrm{ml} / \mathrm{min})$ & $113(18)$ & $109(18)$ & \\
\hline $\begin{array}{l}\text { Urinary } \mathrm{K}(\mathrm{mmol} / 24 \mathrm{~h}) \\
\text { K clearance: }\end{array}$ & $59(22)$ & $38(12)$ & $<0.02$ \\
\hline creatinine clearance $\times 10^{2}$ & $9 \cdot 5$ & $7 \cdot 8$ & $<0.05$ \\
\hline Urinary $\mathrm{Na}(\mathrm{mmol} / 24 \mathrm{~h})$ & $73(39)$ & $36(21)$ & $<0.02$ \\
\hline $\mathrm{Na}: \mathrm{K}$ & $1.40(0.74)$ & $0.93(0.56)$ & $<0.05$ \\
\hline
\end{tabular}

Mean values for serum potassium were $4 \cdot 19$ (SD $0 \cdot 36)$ and $4 \cdot 15(0 \cdot 46) \mathrm{mmol}(\mathrm{mEq}) / 1$ on the two days before indomethacin and $4 \cdot 40(0.39), 4 \cdot 36(0.20)$, and $4.26(0.27)$ on the three days during indomethacin. Although in some subjects serum potassium concentrations rose, the changes for the group of eight subjects were not statistically significant. However, 24 hour urinary potassium excretion and fractional excretion of potassium fell. Besides potassium retention sodium retention also occurred. This is a well known phenomenon during indomethacin therapy and is probably due to both a proximal and distal tubular effect. In fact in our subjects the sodium:potassium ratioalso decreased.

Thus indomethacin treatment induced potassium retention in healthy volunteers. This was accompanied by sodium retention and by a fall in plasma renin activity and plasma aldosterone concentration. Our data on the sodium:potassium ratio, however, do suggest that potassium retention is not only due to changes in aldosterone. Probably more important is the fall in sodium available for distal tubular reabsorption and thus for sodiumpotassium exchange.

Department of Medicine,

PAul E DE Jong

State University Hospital,

Groningen,

Netherlands

\section{Impressions of medicine in India}

SIR,-Dr Tessa Richards's impressions of medicine in India (6 April, p 1047-4 May, p 1329) made sad reading, not because of the sad state of affairs she reports, but because of the pessimistic tone that pervades her report. After an initial disclaimer about the impossibility of doing India in three and a half weeks, she has proceeded to do just that, making sweeping generalisations based on isolated statements from the discontented doctors she seems to have met.

Among several examples of these is her comment about management expertise. The need of it 